\title{
Artikel
}

\section{De aanval is de beste verdediging}

\author{
Het indammen van witwaspraktijken in de professionele voetballerij
}

Mr. drs. P. Steenwijk en prof. dr. mr. H. Nelen*

\section{Introductie}

In mei 2018 werden in Zuid-Limburg ongeveer gelijktijdig vreugdetranen vergoten en bittere tranen geplengd. In Sittard vlogen de trouwe voetbalfans elkaar dolgelukkig om de hals na de tamelijk onverwachte promotie van Fortuna Sittard naar de eredivisie. Vijftien kilometer verderop zaten ontroostbare fans van Roda JC verslagen op de tribune nadat hun club in de play-offs het onderspit had gedolven tegen Almere City en degradatie naar de Eerste Divisie - met ingang van dit seizoen getooid met de niet bepaald sprankelende aanduiding 'Keuken Kampioen Divisie' - niet meer kon worden afgewend. Afgezien van het feit dat beide clubs in dezelfde regio geworteld zijn, hebben zij als gemeenschappelijk kenmerk dat sinds kort buitenlandse investeerders hun invloed op het clubbeleid doen gelden. Bij Roda JC dook in 2016 de in Dubai woonachtige Rus Aleksei Korotaev op. Hij werd vergezeld door voormalig topspeler Nicolas Anelka, die bij de club een rol als adviseur zou moeten gaan vervullen. Korotaev zorgde er met een financiële injectie van enkele miljoenen voor dat in de winterstop van het seizoen 2016/2017 maar liefst zeven nieuwe spelers hun entree in Kerkrade maakten. Het feit dat een aantal van deze spelers niet eens wist waar ze precies waren beland en dat slechts een enkeling speeltijd kreeg, werkte nog enigszins op de lachspieren, maar de aanhouding van Korotaev in februari 2017 na

* Mr. drs. P. Steenwijk is docent risicomanagement aan de Haagse Hogeschool en externe promovendus aan de Universiteit Maastricht. Prof. dr. $\mathrm{mr}$. H. Nelen is hoogleraar criminologie aan de faculteit der rechtsgeleerdheid van de Universiteit Maastricht. een beschuldiging van het uitgeven van een ongedekte cheque, deed het lachen in voetbalminnend Nederland wel vergaan. Hoewel de rechtszaak in Dubai Korotaev slechts in beperkte mate lijkt te schaden - de oorspronkelijke veroordeling tot een vrijheidsstraf werd omgezet in een geldboete en in april 2018 oordeelde de rechter dat diens handtekening door medewerkers van een concurrerend bedrijf vervalst was - is hij nog steeds niet van alle juridische zorgen bevrijd. Roda JC hoopt wel nog steeds zaken met hem te kunnen doen. ${ }^{1}$

Fortuna Sittard wordt sinds twee jaar in financieel en bestuurlijk opzicht geleid door Isitan Gün, een Turkse econoom op wiens cv wordt vermeld dat hij na een carrière in de financiële wereld belandde bij de topclub Galatasaray S.K. In het kielzog van deze Turkse ondernemer streek nog een aantal Turkse zakenlieden in Zuid-Limburg neer, onder wie de 25-jarige accountant die club en geldschieter aan elkaar koppelde en nu verantwoordelijk is voor de boekhouding, en een nieuwe directeur voetbal en scout spelers. Interessant is ook de aanwezigheid van de (voormalige?) eigenaar van het Turkse spelersagentschap PMH Management \& Consulting. Voormalig staat hier met opzet tussen haakjes en met een vraagteken vermeld. Volgens Gün is de bewuste zaakwaarnemer namelijk al tijden niet meer bij het agentschap betrokken, maar uit informatie van de Turkse Kamer van Koophandel blijkt dat zijn naam nog steeds wordt onder de kop 'Management \& Staf' wordt vermeld. ${ }^{2}$

1. Volgens berichtgeving in De Limburger/Het Limburgs Dagblad d.d 11 juni 2018 is door Korotaev aan het noodlijdende Roda JC in ruil voor $20 \%$ van de aandelen 2 miljoen euro op de bankrekening overgemaakt. Dat bedrag stond al sinds januari 2017 geparkeerd op een bankrekening bij een notaris in Heerlen.

2. Peildatum 2 maart 2018 
Het feit dat hierboven de spelerscarrousel bij Roda en de mogelijke betrokkenheid van een spelersmakelaar bij Fortuna expliciet zijn genoemd, heeft een reden. Ondanks het feit dat bij beide clubs geen aanwijzingen bestaan dat de investeringen die zijn gedaan een wederrechtelijke herkomst hebben, is uit de literatuur bekend dat bij het witwassen van crimineel geld in het professionele voetbal de transfer van spelers een belangrijk vehikel is. In dit artikel staat deze thematiek centraal. Na een korte uiteenzetting van de redenen waarom het professionele voetbal zich bij uitstek leent voor het witwassen van crimineel vermogen via de transfermarkt, wordt ingezoomd op de vraag welke mogelijkheden bestaan om dammen tegen dit fenomeen op te werpen. Daarbij wordt in het bijzonder aangehaakt bij de maatregelen die van lidstaten worden verwacht in het kader van de inmiddels vijfde anti-witwasrichtlijn. Bediscussieerd zal worden welke mogelijkheden de in Nederland bij witwasbestrijding en -preventie betrokken partijen hebben om malafide praktijken in het voetbal tegen te gaan en in hoeverre en op welke wijze zij daarvan gebruikmaken.

\section{Witwassen via de transfermarkt}

Onder witwassen van wederrechtelijk verkregen voordeel wordt in het kader van dit artikel verstaan het verhullen van de herkomst van vermogen in de wetenschap dat dit vermogen uit enig misdrijf afkomstig is. In Nederland is witwassen strafbaar gesteld in artikel 420 bis $\mathrm{Sr}$.

In een aantal recente publicaties is reeds gewezen op de witwasrisico's die aan het professionele voetbal, en aan de handel in voetballers in het bijzonder, zijn verbonden. ${ }^{3}$ Het moderne topvoetbal fungeert niet alleen als een speeltje voor verveelde, megalomane miljardairs, maar is ook verworden tot een smeermiddel voor het afsluiten van grote businessdeals, die de nieuwe mondiale economische machtsverhoudingen blootleggen. Voetbalclubs zijn zakelijke pleisterplaatsen en knooppunten, waarin Russische oligarchen, Chinese ondernemers en sjeiks uit de Golfstaten investeren om hun economische en politieke invloedssfeer uit te breiden. De exorbitante bedragen die in deze wereld omgaan, de talrijke mogelijkheden die bestaan om de herkomst van de investeringen te verhullen, de gesloten cultuur en het gebrek aan structureel toezicht op de geldstromen vormen echter

3. Zie, onder andere: H. Nelen, 'Merci Mecenas; witwassen in het professionele voetbal', Orde van de Dag 2015a, 70: 45-53; H. Nelen, 'Professional Football and Crime. Exploring terra incognita in studies on whitecollar crime', in: J. van Erp, W. Huisman \& G. Vander Walle (eds.), Routledge Handbook of White-Collar and Corporate Crime in Europe, Oxford/New York: Routledge 2015b, p. 292-303; H. Nelen, ‘Having the Blues: Money Laundering in Professional Football', in: H. Nelen \& D. Siegel (eds.), Contemporary Organized Crime. Developments, Challenges and Responses, New York: Springer 2017, p. 125-138; Th. de Jong \& M. Aelen, 'Uit het veld. Indirect toezicht op integriteitsschendingen in de voetbalsector', Tijdschrift voor Toezicht 2017 (1) 4, pp. 5-10. ook ideale omstandigheden die investeringen door 'criminele' ondernemers kunnen bevorderen. De Panama en Paradise Papers hebben nog eens bevestigd dat de financiële afwikkeling van transacties/transfers over vele schijven en landen loopt, waarbij niet zelden een belastingparadijs een tussen- of eindstation van de transactie is. Uit de witwasliteratuur weten we verder dat markten waarop de objectieve waarde van objecten moeilijk is te bepalen - zoals vastgoed en kunst - zich goed lenen voor prijsmanipulatie. ${ }^{4}$ Voor de waarde van spelers geldt hetzelfde en dit kan ertoe leiden dat deze waarde kunstmatig wordt verhoogd of verlaagd. Soms worden ook spelers in pakketten verkocht - denk aan de in de inleiding genoemde carrousel bij Roda JC - waarbij de waarde van individuele spelers helemaal niet meer is te bepalen. Door een speler te verkopen aan een club van een 'bevriende' eigenaar, waarbij de prijs op papier wordt opgedreven en de schijn wordt gewekt dat er meer is betaald dan in werkelijkheid het geval is, kan crimineel geld dat in de eigen club is gestoken, vrij eenvoudig worden witgewassen. Andersom levert een te dure aankoop een overgewaardeerd vermogensbestanddeel in de boekhouding op.

Behalve witwasmotieven kunnen er ook andere redenen zijn om in de officiële registraties van getransfereerde spelers andere bedragen te vermelden dan er feitelijk zijn betaald. In verschillende publicaties is melding gemaakt van zogenaamde Bungs, ofwel smeergeld dat buiten de spelersovereenkomst wordt uitgekeerd aan agenten, spelersmakelaars, coaches en de spelers zelf. ${ }^{5}$ Wat de laatsten betreft zijn er natuurlijk nog andere belangen in het geding dan de club waar wordt gespeeld: de inkomsten van hedendaagse topvoetballers worden voor een belangrijk deel bepaald door portretrechten, individuele sponsorcontracten en andere lucratieve overeenkomsten. Dat ook in die sfeer regelmatig wordt gesjoemeld blijkt onder andere uit het feit dat de twee supersterren van het laatste decennium, Lionel Messi en Cristiano Ronaldo, beiden in Spanje zijn vervolgd voor belastingfraude. ${ }^{6}$

In 2009 publiceerde de intergouvernementele organisatie Financial Action Task Force (FATF) een rapport over de verschillende witwasmethoden die in het voetbal

4. Nelen, H. Tussen de stenen; een criminologische blik in de keuken van het commerciële vastgoed. In: G. Vande Walle en P. Van Calster (red.). De criminologische kant van het ondernemen. Den Haag: Boom Juridische uitgevers, 2008, pp. 81-96.

5. Zie o.a. R.V. van der Meij, 'Players, Agents and the Regulatory Framework on the Corruption in International Sports Law', International Sports Law Journal 2009 (1/2): 43-57.

6. Lionel Messi werd in juli 2016 veroordeeld tot een vrijheidsstraf van 21 maanden voor het ontduiken van 4,1 miljoen euro aan inkomstenbelasting. Omdat celstraffen lager dan twee jaar in Spanje worden omgezet in een voorwaardelijke sanctie voor personen zonder strafblad, hoefde Messi niet de cel in. Cristiano Ronaldo wordt verdacht van belastingontduiking van 14,7 miljoen. Zijn aanbod in maart 2018 om de zaak met de Spaanse fiscus te schikken werd niet aanvaard en hij werd gedaagd om op 31 juli bij de Spaanse rechtbank te verschijnen. De uitkomst van deze strafzaak was op het moment van schrijven van dit artikel nog niet bekend. Zie https://www.nu.nl/algemeen/4781052/vanbelastingfraude-beschuldigde-ronaldo-moet-31-juli-voorkomen.html. 
werden gebruikt. Op basis van een aantal vraaggesprekken en een uitgebreide literatuurstudie werd geconstateerd dat de complexe relaties tussen de verschillende stakeholders (clubs, sponsors, agenten, media, individuele investeerders, lokale bestuurders) fungeren als een ecosysteem waarin criminaliteitsvormen als corruptie, belastingontduiking, fraude en witwassen welig konden tieren $^{7}$. In de risicoanalyse van de FATF werd behalve op financiële en structurele factoren - zoals de complexe stakeholdersrelaties, het vaak weinig professionele management en de aard van het transfersysteem - ook gewezen op culturele factoren die het witwassen van crimineel geld bevorderen, dan wel een slagvaardige aanpak daartegen in de weg staan. De eerste factor betreft de vrees om het imago van de sport aan te tasten, hetgeen kan leiden tot wegkijkgedrag of andere ontkenningsmechanismen. Sponsorbelangen spelen hierbij ook een rol. Geen enkel bedrijf wil openlijk worden geassocieerd met criminele praktijken. Een tweede belangrijk aspect betreft het verwerven van status en macht. Voetbalclubs kunnen voor witteboordencriminelen niet alleen een vehikel zijn voor het witwassen van illegaal verkregen inkomsten, maar bieden deze investeerders ook een podium, waarmee zij in de zakelijke en sociale omgeving goodwill en respect op kunnen bouwen en politieke en economische ambities kunnen verwezenlijken.

\section{De strijd tegen witwassen; beleid en actoren}

De discussie over de bestrijding van witwassen in het betaalde voetbal dient te worden gevoerd binnen de context van de vraagstukken die verbonden zijn met de Nederlandse witwasbestrijding in het algemeen. De uitgangspunten van de internationale witwasbestrijding worden bepaald door de eerdergenoemde FATF. De 40 anbevelingen met repressieve en preventieve antiwitwasmaatregelen van de FATF fungeren de facto als internationale normen en vormen de basis van vrijwel alle internationale anti-witwasregimes. ${ }^{8}$ De bestrijding van witwassen en terrorismefinanciering is een van de Europese prioriteiten. De Europese Unie heeft de FATF-normen grotendeels overgenomen en sinds 1991 uitgewerkt in vier opeenvolgende anti-witwasrichtlijnen, waarbij in de loop der tijd ook uitgangspunten voor de bestrijding van de financiering van terrorisme zijn opgenomen (AML-CTF). De huidige, vierde, AMLCTF Richtlijn is sinds juli 2017 van kracht. ${ }^{9}$ Deze richt-

7. Financial Action Task Force (FATF), Money Laundering through the Football Sector. Parijs: FATF/OECD 2009.

8. FATF 2012, International Standards on Combating Money Laundering and the Financing of Terrorism \& Proliferation, The FATF Recommendations.

9. European Commission 2015, Directive (EU) 2015/849 of the European Parliament and of the Council of 20 May 2015 on the prevention of the use of the financial system for the purposes of money laundering or terrorist financing, amending Regulation (EU) No 648/2012 of the European Parliament and of the Council, and repealing Directive lijnen zijn door de lidstaten omgezet in nationale weten regelgeving. In Nederland betreft dat voornamelijk de Wet ter voorkoming van mitmassen en financiering van terrorisme (Wwft) en de Sanctiemet ( $S W$ ). De bloedige aanslag op het Bataclan theater in november 2016 in Parijs en de onthullingen over de Panama Papers in het voorjaar van 2017 noopten de Europese Commissie om de 4 e richtlijn nog tijdens de implementatieperiode aan te passen. ${ }^{10}$ In de nieuwe, 5e richtlijn worden de eisen van transparantie rond trusts, uiteindelijke belanghebbenden en de registratie van uiteindelijke belanghebbenden aangescherpt. Het anonieme gebruik van elektronische geldproducten (zoals prepaidcards) wordt verboden en virtuele valuta vallen voortaan onder het Europese AML-regime. Hierdoor wordt het gebruik van anonieme transacties met virtuele valuta zeer sterk beperkt. Ook komt er een Europese lijst met hoog-risicolanden. Financiële transacties met hoog-risicolanden dienen voortaan te worden onderworpen aan uitgebreide Europese due diligence-maatregelen. De bevoegdheden en informatierechten van Financial Intelligence Units (FIU's) worden uitgebreid. Zeer belangrijk is dat de lidstaten worden verplicht om centrale registers met informatie over rekeninghouders in te richten. ${ }^{11}$ Het Europees Parlement heeft de voorgestelde wijzigingen in april 2018 geaccordeerd en de lidstaten hebben tot december 2019 om de veranderingen in de nationale wetgeving door te voeren.

Het Europese beleid is primair preventief van aard en gericht op het voorkomen van witwassen door het uitvoeren van klantonderzoek en het melden van verdachte transacties door aangewezen instellingen. Deze instellingen dienen te voldoen aan strikte eisen met betrekking tot klantonderzoek, transactiemonitoring, interne controlemaatregelen, documentbeheer en opleiding van medewerkers. Toezichthouders zien toe op de juiste toepassing van de wetgeving en een speciale organisatie, de FIU, is belast met het registreren en analyseren van de door de instellingen en beroepsgroepen aangeleverde meldingen over mogelijke witwas-gerelateerde transacties. Naast banken, verzekeraars en andere financiële instellingen is de richtlijn onder meer van toepassing op makelaars, externe accountants, gokhuizen, notarissen en advocaten. Voor handelaren in goederen geldt een meldingsdrempel voor contante betalingen vanaf 10.000 euro. $^{12}$

2005/60/EC of the European Parliament and of the Council and Commission Directive 2015.

10. Commission Staff Working Document 2016. SWD 2016223 final. Impact Assessment. Accompanying the document. Proposal for a Directive of the European Parliament and of the Council amending Directive (EU) $2015 / 849$ on the prevention of the use of the financial system for the purpose of money laundering or terrorist financing and amending Directive 2009/101/EC.

11. European Council 2017, No 62009/101/EC.2016/0208 COD. Proposal for a Directive of the European Parliament and the Council amending Directive (EU) 2015/849 on the prevention of the use of the financial system for the purposes of money laundering or terrorist financing and amending Regulation (EU)

12. Zie: http://wetten.overheid.nl/BWBR0024282/2016-08-11. 
Sinds 2005 is het Europese anti-witwasbeleid risicogericht. Voor die tijd gebruikten de meldingsplichtige instellingen een lijst met vastgestelde indicatoren om te bepalen of een transactie al dan niet verdacht was. Met de overstap van rule- naar risk-based werd het voortaan de eigen verantwoordelijkheid van de instellingen om het risico van witwassen in te schatten. De te nemen maatregelen voor de detectie van witwastransacties worden sindsdien afgestemd op het ingeschatte risiconiveau (hoog dan wel laag). De nieuwe benadering betekende dat er geïnvesteerd moest worden in risicomethodieken, maar schiep tevens ruimte voor maatwerk en eigen verantwoordelijkheid voor de meldingsplichtige instellingen. Met de introductie van de risicogerichte aanpak is bovendien de verantwoordelijkheid voor de uitvoering van het anti-witwasbeleid in belangrijke mate verschoven van de publieke sector naar private actoren. ${ }^{13}$

De Nederlandse aanpak volgt goeddeels het Europese anti-witwasbeleid. Wel hanteert Nederland een zeer ruime definitie van het begrip witwassen. Een ander belangrijk verschil is dat Nederland een van de weinige lidstaten is die instellingen geen verdachte, maar ongebruikelijke transacties laat melden. De Wwft 2018 bevat overigens geen nadere omschrijving van het begrip ongebruikelijk. Voor de uitvoering van het anti-witwasbeleid werken de verantwoordelijke departementen van Justitie en Financiën, meldingsplichtige instellingen, toezichthouders, de FIU, opsporings- en rechtsprekende instanties samen in de anti-witwasketen. De FIU onderzoekt en analyseert de aangeleverde meldingen en bepaalt welke worden opgewaardeerd tot verdachte transactie. Vervolgens is het aan het Openbaar Ministerie en de opsporingsinstanties (zoals de Fiscale inlichtingen- en opsporingsdienst (FIOD), politie etc.) om op de meldingen door te rechercheren. Door de relatief lage drempel in Nederland wordt er veelvuldig gemeld. Het aantal meldingen is tussen 2013 en 2017 verdubbeld tot ruim 400.000 . Iets meer dan 10 procent daarvan is door de FIU gekwalificeerd als verdacht en vervolgens voor nader onderzoek doorgespeeld aan de opsporingsinstanties. $^{14}$

Over de effectiviteit van de Nederlandse anpak en de organisatie van de meldingsketen bestaat geen duidelijk beeld. Witwasbestrijding is in het algemeen een ingewikkelde en kostbare zaak, waarvan de resultaten lastig te meten zijn. Wereldwijd wordt naar schatting slechts 0,2 procent van het criminele vermogen onderschept. ${ }^{15}$ Ook in Nederland lijkt de kans dat vermogens met een criminele herkomst worden gedetecteerd en ontnomen relatief gering te zijn. ${ }^{16}$ Betrouwbare en valide gegevens

13. M. Bergstrom \& H.M. Svedberg, 'A new role for profit-actors? The case of anti-money laundering and risk management', Journal of Common Market Studies 2011, Volume 51, issue 1.

14. FIU 2017, Jaarverslag FIU-Nederland 2016.

15. UNODC 2004.

16. Algemene Rekenkamer, Bestrijden van witwassen en terrorisme financiering, 2008. Zie ook: B. Unger, et al., The economic and legal effectiveness of the European Union's anti-money laundering policy, Edward Elgar 2014; P. Steenwijk, 'A Balanced Package: Fighting Money voor het beoordelen van de Nederlandse inspanningen zijn echter vooralsnog niet beschikbaar. Bovendien verstrekt de FIU geen informatie over de follow-up van de aangemelde transacties. Voor de FIU lijkt het succes van het beleid vooral afgemeten te worden aan het aantal meldingen. Hierdoor lijkt melden enigszins een doel op zichzelf te zijn geworden. Op zichzelf genomen is het aantal meldingen echter geen indicatie van toegenomen effectiviteit. De econoom Takats heeft de in het systeem ingebakken impuls dat aanzet om zoveel mogelijk te melden 'Crying Wolf' genoemd. ${ }^{17}$ Door instellingen te stimuleren om zoveel mogelijk te melden worden FIU's geconfonteerd met tamelijk veel vals-positieve meldingen en extra kosten. Bovendien worden op deze manier energie en aandacht weggetrokken van de werkelijk risicovolle transacties. Onderzoek in de Verenigde Staten en Italië suggereert dan ook dat het niet zozeer om het aantal als wel om de kwaliteit van de meldingen en de bruikbaarheid als bronnen gaat voor het ontrafelen van witwaszaken. ${ }^{18}$ Een voorzichtige reconstructie van de resultaten gemeten in termen van onherroepelijke veroordelingen en afgenomen vermogen op basis van gegevens uit 2012 wijst uit dat minder dan 3 procent van alle verdachte transacties uiteindelijk in strafzaken is gebruikt waarin het $\mathrm{OM}$ jegens een of meer van de verdachten een vervolging heeft ingesteld. Dat is minder dan 1 procent van de oorspronkelijke aangemelde ongebruikelijke transacties. ${ }^{19}$ Het bedrag aan wederrechtelijk verkregen vermogen dat het $\mathrm{OM}$ uiteindelijk weet te ontnemen van witwassers is de afgelopen jaren toegenomen. Maar het lijkt qua omvang beperkt als het wordt afgezet tegen het geschatte totale volume aan crimineel en witgewassen vermogen in Nederland. ${ }^{20}$ Daarnaast wordt het beeld vertekend door de impact van individuele, omvangrijke zaken. Een groot deel van dit bedrag was bijvoorbeeld afkomstig van de schikking met SBMOffshore ter grootte van 200 miljoen dollar. ${ }^{21}$

Meer in het algemeen ontbreekt het aan duidelijke doelstellingen, prioriteiten en regie binnen de meldketen. In 2014 concludeerde de Algemene Rekenkamer dat ondanks forse investeringen er niet meer inzicht bestaat in de oorzaken van witwassen en de effectiviteit van het beleid. ${ }^{22}$ Ook de witwasmonitor van het ministerie van Justitie is niet meer dan een eerste, globale aanzet om de prestaties van het beleid in kaart te brengen..$^{23}$ Overigens is de Nederlandse situatie allesbehalve uniek voor wat betreft het gebrek aan inzicht in de effecten en opbreng-

Laundering with the 4th European Directive', in: J. de Zwaan, M. Lak, M. Makinwa \& P. Willems (eds), Governance and Security Issues of the European Union, challenges ahead, New York: Springer 2016.

17. E. Takats, 'A Theory of "crying wolf"', IMF 2007, p. 381

18. L.D. Pellegrina \& D. Masciandaro, 'The risk based approach in the new European anti- money laundering legislation', in: Bocconi University Paolo Baffi Centre Research Paper Series 2005, No. 2008-22.

19. Algemene Rekenkamer 2014, Bestrijden witwassen stand van zaken 2013.

20. KLPD 2013, Witwassen, Criminaliteitsbeeld Analyse 2012.

21. Openbaar Ministerie 2015, Jaarbericht 2014.

22. Algemene Rekenkamer 2014.

23. Decide 2015, De bestrijding van witwassen. Beschrijving en effectiviteit 2010-2013. Startversie monitor anti-witwasbeleid 
sten van het nationale anti-witwasbeleid. Hoewel het Europese kader in artikel 44 voorschrijft dat de lidstaten de baten en de lasten van het beleid dienen te analyseren, is dat tot op heden in vrijwel geen enkel land goed van de grond gekomen. ${ }^{24}$

\section{Preventie van witwassen in de voetballerij: partijen, instrumenten en beleid}

Van oudsher zijn de Europese voetbalbonden tamelijk autonoom in het bestieren van hun interne zaken. ${ }^{25}$ De Europese Commissie is ook teruggekomen op het eerdere voornemen om de Europese AML-richtlijn uit te breiden tot het professionele voetbal. ${ }^{26}$ Binnen de Europese instellingen wordt de opvatting gehuldigd dat zelfregulering door sportbonden de beste manier is om intracommunautaire solidariteit en fair play te bewerkstelligen. Dit verklaart waarom binnen het sportdomein is afgezien van de traditionele implementatie van de verdragsregels van de Europese Unie. ${ }^{27}$ Nederland is een van de landen waar geen publiekrechtelijke juridische kaders zijn ingericht voor het reguleren van de transfer van spelers en het optreden van spelersmakelaars. Deze zaken behoren tot het exclusieve domein van de KNVB en UEFA. De clubs uit het betaalde voetbal zijn ook geen meldingsplichtige instellingen in de zin van de Wwft. Dat betekent dat er geen toezichthouder is die toeziet op de naleving van de anti-witwaswetgeving en dat betaaldvoetbalorganisaties (BVO's) niet onderworpen zijn aan de meldplicht van ongebruikelijke transacties bij FIU-Nederland. Het betaald voetbal valt dus buiten de directe scope van het institutionele anti-witwasmechanisme.

Maar de Wwft is niet het enige instrument om witwassen te voorkomen en signalen te genereren voor de bevoegde instanties. In het verlengde van de metafoor van het voetbalelftal die Boutellier ooit introduceerde voor de veiligheidszorg in het algemeen, kan worden beredeneerd dat de verantwoordelijkheid voor het indammen van witwaspraktijken in de voetballerij verdeeld is over vele instanties. ${ }^{28}$ Elk van die instanties heeft specifieke bevoegdheden en instrumenten. Net als bij Boutellier is de rol van keeper weggelegd voor Justitie. De verdediging bestaat uit de opsporingsinstanties - de politie en FIOD in het bijzonder - en externe toezichthouders, zoals De Nederlandsche Bank (DNB) en

24. Eurostat, Money Laundering in Europe. Report of work carried out by Eurostat and DG Home Affairs, Luxembourg Publication Office of the European Union 2015

25. KEA-CDES 2013 en FATF 2009.

26. KEA-CDES 2013.

27. KEU-CDEA 2013, The Economic and Legal Aspects of Transfer of Players, p. 2

28. H. Boutellier, De Veiligheidsutopie. Hedendaags onbehagen en verlangen rond misdaad en straf, Den Haag: Boom Juridische uitgevers 2003 (tweede, uitgebreide druk). de Autoriteit Financiële Markten (AFM). De opsporingsinstanties kunnen in voorkomende gevallen een opsporingsonderzoek starten, terwijl DNB een systeemrisicoanalyse kan maken en de AFM in het kader van gedragstoezicht bestuursrechtelijke dwang kan uitoefenen of een bestuurlijke boete op kan leggen, als er signalen zijn van onregelmatigheden bij financiële transacties. Op het middenveld treffen we de instituties aan voor wie veiligheid en criminaliteitsbestrijding slechts een afgeleide functie is. In relatie tot het voetbal moet daarbij in het bijzonder worden gedacht aan de internationale en nationale voetbalbonden. Deze organisaties hebben hun eigen doeleinden, maar hebben binnen het veiligheidsparadigma een extra functie toebedeeld gekregen. De voorhoede bestaat uit de clubbestuurders en de sociale relaties waarmee zij in contact staan. En tussen de linies opereren nog tal van andere poortwachters, zoals fiscalisten, accountants, notarissen, advocaten en banken. Deze hebben wel een meldplicht en kunnen zo nodig aan de bel trekken bij de FIU.

Hieronder zullen de verschillende verdedigingslinies nader tegen het licht worden gehouden. In het licht van de Nederlandse traditie van avontuurlijk, aanvallend voetbal beginnen we daarbij met de voorhoede. De verantwoordelijkheid die BVO's zelf hebben om criminele investeringen buiten de deur te houden, wordt bevestigd in de zeer recent door de Koninklijk Nederlandse Voetbalbond (KNVB) aangescherpte licentiebepalingen. Vervolgens is natuurlijk de vraag wat de KNVB, en eventueel in het verlengde daarvan de UEFA en FIFA, zouden kunnen doen als vermoedens van het investeren van onrechtmatig verkregen vermogen in een club bestaan. Tot slot wordt kort stilgestaan bij de rol die aan de toezichthouders en opsporingsinstanties (op gezag van het openbaar ministerie) mag worden toegedicht.

\subsection{De betaaldvoetbalorganisaties}

In een tijd waarin begrippen als bedrijfsethiek en compliance een prominente plaats innemen in de discussie hoe vanuit organisaties kan worden gestimuleerd dat regels worden nageleefd en dammen worden opgeworpen tegen criminele beinvloeding, valt op dat deze discussie aan de professionele voetballerij goeddeels is voorbijgegaan. Er is geen Nederlandse club die gedragsregels heeft opgesteld die maar in de verte raken aan de problematiek die in deze beschouwing centraal staat. Evenmin zijn compliance units gangbaar in de wereld van de professionele voetballerij. Veeleer heeft het er alle schijn van dat de participanten in de voetbalwereld financiële wantoestanden voor lief nemen en volharden in gedrag dat het midden houdt tussen wegkijken, zich afzijdig houden en niet (door)vragen hoe de vork in de steel zit. ${ }^{29}$

Tot voor kort was het voor BVO's tamelijk eenvoudig om de kop diep in het zand te steken, maar aan die situatie is door de KNVB recentelijk een einde gemaakt. In het verleden probeerde de bond na een buitenlandse

29. Nelen 2015a. 
investering en verandering van eigendomsverhoudingen (bij bijvoorbeeld Vitesse en ADO Den Haag) vaak pas achteraf enig zicht op de geldstromen en achtergrond van de financiers te krijgen. Soms werd daarbij ook de hulp van private onderzoeksbureaus en forensische accountants ingeschakeld. In de nieuwe situatie, die van kracht is sinds de wijziging van de licentiebepaling in juni 2018, moet de Licentiecommissie Betaald Voetbal van de KNVB vooraf toestemming verlenen als een partij $25 \%$ of meer van de zeggenschap in een BVO wil verwerven. Bij deze beoordeling wordt gekeken naar de achtergrond van de investeerder en de herkomst en aanwending van diens vermogen. Het stelsel is gebaseerd op een variant van het in de financiële wereld gangbare know-your-customer-principe en wordt in dit geval aangeduid als het know-your-omner-principe. De regels zijn neergelegd in artikel 4 lid 9 van het Licentiereglement Betaald Voetbal en verder uitgewerkt in de Richtlijn Wijziging Zeggenschap en de Richtlijn Waarborgen Onafhankelijkheid en Continuïteit Licentiehouder.

De vraag is natuurlijk wel of de licentiehouders c.q. de clubs voldoende geoutilleerd zijn om door een op papier plausibele constructie heen te prikken. De kern van witwassen is immers dat op papier de schijn wordt gewekt dat het criminele vermogen een legale herkomst heeft. In de Richtlijn Wijziging Zeggenschap stelt de KNVB terecht dat van de Licentiecommissie Betaald Voetbal niet mag worden verwacht dat deze commissie wereldwijd financieel onderzoek doet naar de herkomst van de investeringen, maar impliciet gaat men er in de toelichting van uit dat de clubs daartoe wel in staat zouden zijn. Zelfs met hulp van een forensische accountant zal het echter een geweldige inspanning vergen om door de kerstboom van rechtspersonen de ultimate beneficial omner (UBO), diens zakelijke netwerk en diens financiële achtergrond in kaart te brengen. Bovendien worden eigendomsverhoudingen en financiële injecties vaak versluierd via een U-bocht, zoals het in het voetbal beruchte Third Party-Omnership (TPO). Hierbij verwerft een derde partij de rechten op de toekomstige transferwaarde van de speler in kwestie. TPO maakt het mogelijk voor clubs om met weinig geld en risico waardevolle spelers aan te kopen. In ruil daarvoor staat de club een deel van de toekomstige waardevermeerdering af aan de financier. Het is een praktijk die in Latijns-Amerika is ingeburgerd en gedurende het afgelopen decennium is overgewaaid naar Europa. Los van de morele vraagstukken die TPO oproept - professionele voetballers zijn gereduceerd tot pure handelswaar - is het ook een model van financiering dat zich leent voor witwasconstructies, vaak in combinatie met het gebruik van offshorebetalingen en andere criminele activiteiten als matchfixing, illegaal gokken en competitievervalsing. ${ }^{30}$ Sinds 2015 heeft de FIFA daarom ook besloten dat de TPO-constructie niet meer is toegestaan. ${ }^{31}$ Zoals De Jong en Aelen overtuigend laten zien aan de hand van de

30. KEA-CDES 2013

31. Zie: https://www.knvb.nl/themas/financi\%C3\%ABle-integriteit/thirdparty-ownership. transfer in 2017 van Braziliaanse superster Neymar van Barcelona naar Paris SG, kan dit TPO-verbod (en de Financial Fair Play-regelgeving) echter kinderlijk eenvoudig worden omzeild. ${ }^{32}$

Een ander probleem dat als gevolg van de nieuwe licentiebepalingen kan ontstaan, is dat de zeggenschapsverhoudingen op papier worden verdeeld over meerdere natuurlijke en rechtspersonen teneinde te versluieren wie er daadwerkelijk aan de touwtjes trekt. Uit de witwasliteratuur is zogenaamd 'smurfgedrag' maar al te zeer bekend: betrokkenen zorgen ervoor dat zij net onder de drempel blijven van een in een regeling genoemd bedrag of percentage, zodat er geen meldingsplicht ontstaat of noodzaak tot het doen van nader onderzoek. ${ }^{33}$ Volgens de nieuwe licentiebepalingen kan het Roda JC bijvoorbeeld niet worden verweten als de club geen nader onderzoek doet naar de achtergrond van Aleksei Korotaev. Hij heeft immers maar een aandeel van $20 \%$ in de club.

Een maatregel die zou kunnen worden overwogen om de invloed van externe investeerders in te dammen is te vinden bij onze oosterburen. In Duitsland is namelijk de $50+1$-regel vastgelegd. ${ }^{34}$ Die regel houdt in dat op iedere $\operatorname{club}^{35}$ de inspanningsverplichting rust om te voorkomen dat één partij (in casu één investeerder) meer dan $49 \%$ van de aandelen en zeggenschap heeft over de club. Hoewel ook dit systeem zeker niet feilloos is bij het tegengaan van witwaspraktijken, beschermt het Duitse clubs wel beter tegen het risico volgepompt te worden met vermogen van dubieuze herkomst.

\subsection{De bonden}

In de huidige situatie waarin de sector slechts in beperkte mate is gereguleerd, is een belangrijke rol weggelegd voor de nationale en internationale voetbalbonden. FIFA en UEFA hebben inmiddels schoorvoetend erkend dat er een probleem met witwassen in het voetbal bestaat. Sinds het onderzoek van de FATF zijn er dan ook enkele maatregelen genomen om fraude aan te pakken. De UEFA heeft in 2012 de Financial Fair Play Rules (FFP) ingevoerd om een betere naleving van de transferregels af te dwingen. ${ }^{36}$ De doelen van FFP staan echter vooral in het teken van het vergroten van de financiële stabiliteit van het professionele voetbal. De Europese voetbalfederatie lijkt echter beduidend minder geïnteresseerd te zijn in de integriteit van de

32. De Jong en Aelen 2017

33. Zie bijvoorbeeld $M$. Soudijn \& Th. Akse, 'Witwassen. Criminaliteitsbeeldanalyse', Den Haag: Nationale Politie 2012.

34. Oliver Budzinski of University of Southern Denmark: 'Football and Regulation: Why German Teams Might Win in the End', http://www. playthegame.org/fileadmin/image/knowledgebank/Challengesforfoot ball_pdf/Oliver_Budzinski.pdf.

35. Er zijn in de Bundesliga twee uitzonderingen op deze regel: het eigendom en de zeggenschap over Bayer 04 Leverkusen berusten bij het farmaceutische bedrijf Bayer, die van VFL Wolfsburg bij autofabrikant Volkswagen. Deze verhoudingen gaan verder terug dan het jaar 1999, toen de 50+1-regel werd ingevoerd. RB Leipzig is een voorbeeld van een club die qua financiering volledig afhankelijk is van Red Bull, maar dit bedrijf heeft slechts 17 stemgerechtigde leden in de ledenraad.

36. Zie: http://www.uefa.com/community/news/newsid=2064391.html. 
(rechts)personen die in de financiering van het voetbal een hoofdrol vervullen. ${ }^{37}$ Het Transfer Matching System (TMS) van de FIFA is een web-based systeem voor de uitwisseling en vastlegging van gegevens over internationale transfers. Het TMS laat zien waar het geld vandaan komt, waar het heengaat en bevat informatie over transfersommen, commissies, betalingsschema's en andere betaalinformatie. ${ }^{38}$ Hoe transparant dit systeem op papier ook lijkt, is het, zoals eerder al werd vastgesteld, evident dat bij de transfers van spelers een deel van de gegenereerde opbrengsten en betalingsverplichtingen buiten de boeken blijft en niet in het TMS wordt weergegeven.

In het Verenigd Koninkrijk heeft de tegenhanger van de KNVB een uitgebreide leidraad opgesteld om clubs te helpen om witwaspraktijken te herkennen en te voorkomen. ${ }^{39}$ Eigenaren en managers van professionele Engelse voetbalclubs moeten voldoen aan een aantal objectieve criteria op het gebied van betrouwbaarheid en deskundigheid. De Football Association verplicht hen om vooraf de Omners and Directors test - ook wel aangeduid als de Fit-and-Proper-Persons-test - af te leggen. De test bestaat uit 12 vragen die eenvoudig met ja of nee dienen te worden beantwoord. ${ }^{40}$ De vragen dienen onder meer om vast te stellen of de bestuurder in kwestie zich heeft schuldig gemaakt aan zogenaamde dishonesty offences zoals fraude, diefstal, valsheid in geschrifte, verduistering, corruptie etc. Er wordt concreet gevraagd naar betrokkenheid bij faillissementen, professioneel wangedrag, relaties met andere clubs, niet of slechts ten dele ten uitvoer gelegde veroordelingen, en of er een verbod is opgelegd om een managementfunctie te bekleden op grond van de Company Disqualification Act. ${ }^{41}$ Een vraag met ja beantwoorden, betekent dat de functionaris voldoet aan een van de diskwalificerende criteria en dat hij of zij formeel niet geschikt is bevonden om de positie te bekleden. Het besluit van de bond om een kandidaat na het afleggen van de test al dan niet toe te laten, wordt met de bijbehorende overwegingen openbaar gemaakt. Bestuurders en eigenaren die op een later moment niet meer voldoen aan de fit and proper-criteria zijn verplicht de bond hierover te informeren en hun functie binnen zeven dagen neer te leggen.

Binnen het Verenigd Koninkrijk wordt er verschillend gedacht over het nut van de test die in zijn huidige opzet niet veel meer behelst dan een vragenlijst. De vragen zijn dusdanig algemeen geformuleerd dat het voor de meeste mensen niet moeilijk is om aan de eisen te voldoen. Er zijn ook maar weinig gevallen bekend van mensen aan wie een verbod is opgelegd om manager of eigenaar van een Engelse club te worden. Verder is het lastig om het gedrag van eenmaal toegelaten functionarissen te

37. Nelen 2015a.

38. https://.fifatms.com/itms/.

39. The Football Association 2008, Money Laundering and the Proceeds of Crime Act, Guidance for Football Clubs.

40. Owners and Directors Test, in: rules and regulations of the association, season 2017-2018, p. 310-321.

41. Idem. controleren. Het beperkt aantal uitsluitingen en - belangrijker nog - de toelating van individuen wier financiële handel en wandel ernstig ter discussie is komen te staan, rechtvaardigen de vraag of er geen strengere eisen zouden moeten worden gesteld en of de regels die zijn uitgevaardigd niet stringenter en consequenter zouden moeten worden gehandhaafd. ${ }^{42}$ De regeling is in 2017, op verzoek van een aantal topclubs, overigens op een beperkt aantal, veelal technische, punten aangescherpt. ${ }^{43}$

In de nasleep van het FATF-onderzoek kondigde ook de KNVB, bij monde van de directeur betaald voetbal, aan maatregelen te zullen nemen. Dit ondanks het feit dat het risico op witwassen aanvankelijk als gering werd ingeschat. ${ }^{44}$ De KNVB was vervolgens in 2014 wel een van de eerste bonden die een Domestic Transfer Matching System (DTMS) invoerde om nationale transfers beter te kunnen volgen. ${ }^{45}$ Een andere maatregel die sinds juni 2018 van kracht is, betreft de hiervoor al genoemde toetsing vooraf van de achtergrond en de herkomst en aanwending van het vermogen van de investeerder die een aandeel van 25 procent of meer in een $\mathrm{BVO}$ willen verkrijgen. Ook dient te worden voldaan aan de eisen met betrekking tot Financial Fair Play van de FIFA (artikel 3 lid 5).

\subsection{Toezichthouders en opsporingsinstanties}

Een grondig en diepgaand onderzoek - hetzij door een wetenschappelijk onderzoeksinstituut, hetzij door een opsporingseenheid of toezichthouder - naar de mate waarin en wijze waarop het betaalde voetbal is besmet met crimineel geld, is nimmer uitgevoerd. Wel zijn er in het verleden verschillende opsporingsonderzoeken door de FIOD uitgevoerd naar fraude en belastingontduiking bij clubs. Het heeft er alle schijn van dat binnen deze opsporingseenheid ook in relatie tot witwassen de gang van zaken in de professionele voetballerij beter wordt gevolgd dan een aantal jaren geleden. Ook het OM heeft, getuige de aanstelling van een speciale officier van justitie bij het Functioneel Parket, meer belangstelling voor criminaliteit gerelateerd aan sport gekregen, zij het dat deze belangstelling zich nog niet heeft vertaald in concrete strafrechtelijke onderzoeken en vervolgingen. Hoeveel voetbalgerelateerde meldingen van ongebruikelijke transacties bij de FIU zijn gedaan, is niet publiekelijk bekend, maar dat dit aantal niet bijster hoog zal zijn ligt, gezien de pas recent tot stand gekomen belangstelling voor het thema van de financieel-economische criminaliteit in de sport, in de lijn der verwachtingen.

42. https://www.researchgate.net/publication/283569573_The_FA_Fit_ for_Purpose. Zie ook het artikel van Nelen 2015a, waarin uitgebreid uit de doeken wordt gedaan hoe de voor fraude en witwassen veroordeelde Carson Yeung jarenlang de zaken naar zijn hand kon zetten bij de Engelse club Birmingham FC en de Engelse FA niet ingreep.

43. https://www.eurosport.com/football/efl-clubs-agree-to-tighten-upowners-and-directors-test_sto6208015/story.shtml.

44. R.B.J. Slot, 'Misdaad en Voetbal', Justitiële Verkenningen 2010, jaargang $36 \mathrm{nr} .1$.

45. KEA-CDES 2013 
In 2017 heeft De Nederlandsche Bank bij een aantal banken en trustkantoren onderzocht in hoeverre deze instellingen alert waren op witwasrisico's bij cliënten en transacties die gelieerd zijn aan de voetbalwereld. Uit de steekproef kwam naar voren dat bij de meeste instellingen zowel de risicoperceptie als de bestaande beheersingsmaatregelen tekortschoten. ${ }^{46} \mathrm{DNB}$ beveelt op basis van de bevindingen van de risicoanalyse onder andere aan om banken in hun cliëntenonderzoeken een onderscheid te laten maken tussen reguliere klanten en voetbalklanten en de laatste categorie verder uit te splitsen naar voetballers, bestuurders, aanverwante dienstverleners zoals agenten, managers en makelaar en de bij grote transacties betrokken rechtspersonen. Als de voetbalklant is 'uitgelicht' en er een diepgaander cliëntenonderzoek heeft plaatsgevonden, is het volgens DNB mogelijk om een kwalitatief beter transactieprofiel op te stellen of om transacties te monitoren en mogelijke onregelmatigheden te detecteren. Deze aanbevelingen onderstrepen de noodzaak om indringender naar de in dit artikel besproken problematiek te kijken.

\section{Conclusie}

Witwassen in het professionele voetbal is een onderschat en complex probleem. Vooral transfers zijn kwetsbaar voor manipulatie. In veel gevallen is het onduidelijk met wat voor middelen - legaal, dan wel illegaal verkregen de grootschalige investeringen in het hedendaagse voetbal worden gedaan. Dat is een verontrustende constatering. Niet alleen zorgen witwaspraktijken voor marktbederf en competitievervalsing, maar de mogelijkheid dat voetbal wordt misbruikt als een systeem dat financieeleconomische criminaliteit faciliteert, zou clubbestuurders, bonden, toezichthouders en alle andere betrokkenen die de sport een warm hart toedragen, zorgen moeten baren. Ondanks dat de periode van wegkijken en ontkenning voorbij lijkt te zijn en langzamerhand het besef doordringt dat meer aandacht nodig is voor de aard en omvang van het probleem en voor de tegenmaatregelen die kunnen worden genomen om dat probleem in te dammen, staat het anti-witwasbeleid binnen het professionele voetbal nog in de kinderschoenen. Veelbetekenend is dat in de vijf Europese anti-witwasrichtlijnen de sport buiten de reikwijdte van de bepalingen is gehouden en dat breed de opvatting wordt gehuldigd dat de voetballerij door middel van zelfregulering en compliance zelf dammen moet opwerpen tegen criminele investeringen. De know your omner (KYO)-bepaling in het nieuwe licentiereglement van de KNVB past in die trend. Deze bepaling onderstreept dat de verantwoordelijkheid voor het weren van criminele investeringen en beinvloeding primair bij de clubs ligt. De KNVB lijkt de mogelijkheden die BVO's hebben om de achtergrond van potentiële investeerders te controleren en de herkomst van het vermogen te achterhalen, wel enigs-

46. DNB 2017, Integriteitsrisico's rond de voetbalsport. zins te overschatten. Er blijft op dat gebied ook een belangrijke verantwoordelijkheid bestaan voor de KNVB zelf - en de internationale bonden UEFA en FIFA. De ervaringen met de Fit-and-Proper-Persons-test die door de Engelse Bond wordt gehanteerd, leren dat een toetsing vooraf niet voldoende is, maar dat de geschiktheid van eigenaren en bestuurders ook na toelating gevolgd dient te worden. De KNVB heeft zich over de wenselijkheid van een dergelijk screeningsmechanisme in Nederland nog niet openlijk uitgesproken. Het zou interessant zijn om na te gaan in hoeverre een op Nederlandse leest geschoeide Fit-and-Proper-Personstest van toegevoegde waarde kan zijn bij het bewaken van de financiële integriteit van de voetbalsector. Die test zou dan wel meer moeten behelzen dan het afnemen van een vragenlijst en zich wellicht niet alleen moeten toespitsen op bestuurders en eigenaren, maar ook op agenten en spelersmakelaars. ${ }^{47}$ Analoog aan de gang van zaken in het kader van de screening die plaatsvindt op basis van de Wet bevordering integriteitsbeoordelingen door het openbaar bestuur (Bibob), is een constructie denkbaar waarin de KNVB bij twijfel of een licentie of vergunning moet worden verstrekt of verlengd, een advies vraagt bij een publiekrechtelijke onderzoeksinstantie, die voor dat advies ook informatie uit gesloten bronnen kan raadplegen. Een dergelijke constructie zal goed juridisch verankerd moeten worden, maar de grondgedachte ervan sluit aan bij de publiek-private samenwerking die voor het tegengaan van witwassen geboden is. Op die manier kan ook een brug worden geslagen tussen sportbonden enerzijds en publiekrechtelijke toezichthouders en opsporingsinstanties anderzijds. Gelet op het brede onbehagen over de integriteit van de sector en in het belang van de internationale strijd tegen witwassen en georganiseerde misdaad is een brede, integrale aanpak van het probleem noodzakelijk. Dat blijkt ook uit het in juli 2018 door het programma Politie \& Wetenschap gepubliceerde rapport over ondermijning door criminele weldoeners. ${ }^{48} \mathrm{Op}$ het internationale voetbaltoneel is het Nederlands elftal de afgelopen jaren helaas wat weggezakt, maar beleidsmatig kan Nederland een koppositie veroveren door het voortouw te nemen in de formulering van gericht anti-witwasbeleid in de sector en de daadkrachtige aanpak daarvan. Daarvoor is, om dicht bij de metafoor van het voetbalelftal te blijven, een goed op elkaar ingespeeld team noodzakelijk. Nederland is wereldberoemd geraakt door zijn avontuurlijke stijl van (totaal)voetbal, waarbij het accent lag op de aanval. En laat de aanval nu ook de beste verdediging zijn in de witwasbestrijding. weldoeners, Den Haag: Politie \& Wetenschap 2018. 